DOI https://doi.org/10.18551/rjoas.2021-01.03

\title{
THE EFFECT OF VILLAGE FUND MANAGEMENT ON THE DEVELOPMENT OF THE COMMUNITY ECONOMIC STRUCTURE OF WATODIRI VILLAGE, ILE APE SUBDISTRICT, LEMBATA DISTRICT, INDONESIA
}

\author{
Sinu Ignatius ${ }^{*}$, Klau Fidelis \\ University of Nusa Cendana, Indonesia \\ *E-mail: ignatius.sinu@gmail.com
}

\begin{abstract}
Economic, social and cultural symptoms and phenomena of the rural society are also confirmed to be influenced by the Village Fund intervention and the allocation and management of the Village Fund by the village institutions. The central government policy allocates a number of budgets directly to the village to be managed according to the needs, enabling villages and village communities to have facilities in planning and carrying out economic activities in the village in order to create jobs, ensuring job security for workers in the village, availability of funds to optimize the potentials that have been difficult to move with capital constraints. This research was aimed at examining models of empowerment of rural communities with the support or use of the Village Fund, which further looks at the effect of the realization of activities on the socio-economic structure of village communities. The results of the study show that the Watodiri Village community economic empowerment program with the assistance of the Village Fund has a low influence on the strengthening of the economy of the villagers, with constraints on local politics that do not favor community economic empowerment.
\end{abstract}

\section{KEY WORDS}

Influence of management, village fund, development, eoconomic structure, village community.

The realization of development goals and empowerment of village communities depend on the conditions of the village community itself. In relation to the study of the economic structure of rural communities it is always described in terms of being poor, low incomes, and even the powerlessness of the community. The study with the approach to the economic structure of the village community that was explored was about the economic activities of the village community that affect the progress of development at the village level. Economic activities at the village level vary, to the point that they are often classified as odd economic activities, activities with an adequate amount of labor and capital but providing very low income contributions, and income contributions that contribute to poverty in the village. The Village Fund that has entered the village every year since 2015 should have gone very far in providing answers to the economic structure of rural communities, from simple to increasingly complex, to market competition at a higher level. Economic expansion out of the village to other villages to the urban sector should also be an indicator of the success of Village Fund management. This study is an economic anthropology study whose urgency is to raise the values of empowerment in the structure of economic activities at the village level. The low understanding of the economic structure of rural communities has an effect on the inadequacy of rural economic empowerment programs.

\section{METHODS OF RESEARCH}

This research is a descriptive study based on the strength of qualitative analysis. Koentjaraningrat (1984) said that the key to success of qualitative analysis is in detailed field data in the form of direct observation and interviews. Detailed empiric data and direct interview data, which have a high level of trust, and which are suitable as data for analysis can only be collected through careful interviews and observations. 
Field data collection using interview approach both using questionnaires, in-depth interviews using interview guidelines, focussed group discussions and direct observation. The result is a large and varied amount of data. Therefore the next step is to select data by tabulating and classifying. In the tabulation format, problem identification will be carried out, then problems related to the research objectives will be found, hypotheses are made and hypotheses are based on the theories and concepts of this research.

The approach used in this study is the agricultural development approach. This approach is carried out to understand the process of agricultural development and the economic life of the farming community in the region, especially in Watodiri Village. The principle carried out in field research activities is the principle of action research as developed by John Eliot (in Hopkkins, 1993). John Eliot explained that action research is a study of social situations with the aim of improving the quality of action in these social situations. Action Research is a systematic collection of data about daily practices and analyzing it to make decisions about practices that should be carried out in the future (Wallace, 1998, in Burns, 1999). Thus, AR is a study of practical situations in certain social situations to make improvements or improvements or make changes in the future. Actioan Research which is characterized by (1) all people in all contexts in which they are located can be researchers; (2) focus on learning: AR helps learning both individually and collectively; (3) responsive to social situations: social dynamics are a concern for making adjustments and changes; (4) the practitioner (researcher) is responsible for his own actions: decisions are based on his own knowledge and experience, not on orders from outside; (5) AR emphasizes values as the basis of practice: always questions the choice of values that are believed to be their actions.

\section{RESULTS AND DISCUSSION}

Watodiri is one of the villages in the Ile Ape District. Meanwhile, lle Ape District is one of the sub-districts of the nine sub-districts in Lembata Regency, East Nusa Tenggara Province. The area of lle Ape sub-district before 2005 includes all villages at the foot of the Ile Ape Mountain, or villages scattered in the flat area surrounding the lle Ape Mountain. All villages in this area are coastal villages, but the residents make a living as semi-permanent agricultural farmers with staple crops of maize and cassava. Due to its low natural capacity, villagers in lle Ape have a habit of leaving their village to migrate to other areas. Favorite overseas destination is Malaysia. Villagers in Ile Ape Subdistrict leave their village to go overseas with the aim of building their hometown.

The area of Watodiri village is $5.87 \mathrm{~km} 2$. This village is located at an altitude of $0-100$ $\mathrm{m}$ above sea level. Watodiri villagers live concentrated in several relatively flat coastal areas with relatively good soil ferti ity (alluvial-volcanic). The area of Watodiri village is relatively flat with a dominant slope of 120 and in the interior or mountainous area, it has a slope of 300400. The village is located on the seashore of Hadakewa Bay, which is rich in marine products, but the people are $100 \%$ farmers; semi-settled field farmers.

Watodiri consists of 4 hamlets and $8 \mathrm{RTs}$; it is $4 \mathrm{~km}$ from the sub-district center with a travel time of 25 minutes, and to the district capital $10 \mathrm{~km}$ with a travel time of 30 minutes. This village is very easy to reach, because it is close to the sub-district and regency capitals. It has been reached by a paved highway which is always passed by two- and four-wheeled vehicles. It is easy for the villagers to travel outside the village because almost every family owns a two-wheeled vehicle. In this village there are two special pick-up vehicles serving the villagers of Watodiri who commute to and from selling salt and palm sap to the Pada market in Lewoleba every day. This vehicle departs from Watodiri village to the market at $08.00 \mathrm{am}$ and at 10.00 returns to Watodiri. At 13.00 back to the On market, and at 17.00 back to Watodiri. This schedule is the daily schedule for the two picks belonging to residents who serve Watodiri villagers traveling especially to potential traditional markets to sell salt and palm sap.

The education level of the Watodiri villagers is low, on average they graduate and do not finish elementary school. There are some people from this village who are successful in 
the world of education, in the sense of attending school and becoming a graduate, but they choose to stay and breed in the city, both working in government agencies and working as civil servants, company employees, drivers, craftsmen, shopkeepers, entrepreneurs and / or self-employed.

It is very difficult to trace the potential source of income which is also the economic base of the Watodiri villagers. The curiosity that is the hidden target of this research is that if the villagers of Watodiri are not migrants, what is the economic basis that causes this village community to be able to build their village? Outsiders who come to Watodiri Village can also conclude that this village is progressing because its inhabitants are fishermen. Fishing activities have certainly contributed greatly to the progress of development in this village. Moreover, it is supported by the "Muru"1 tradition, a marine conservation tradition known for generations. However, none of the residents of Watodiri village, which borders the sea and has a tradition of "muru" (marine conservation), chose to work as fishermen. In the economic structure of the Watodiri village community, the fishing sector is at the bottom of the structure.

Table 1 - The Economic Structure of the Watodiri Village Community Based on Contribution to Respondents' Household Income

\begin{tabular}{|l|l|l|l|}
\hline Num & Type of Work & Income (RP) & $\%$ \\
\hline 1 & Palm Tapping & 1.053 .000 .000 & 43.00 \\
\hline 2 & Traditional Salt Industry & 696.000 .000 & 28.17 \\
\hline 3 & Livestock & 345.625 .000 & 13.99 \\
\hline 4 & Red Brick Business & 234.000 .000 & 9.47 \\
\hline 5 & Traditional Settled Cultivation & 124000000 & 5.19 \\
\hline 6 & Traditional Weaving & 18250000 & 0.74 \\
\hline 7 & Fisherman & 0 & 0.00 \\
\hline Total & & 2470875000 & 100 \\
\hline
\end{tabular}

The World Bank in 2020 (see also George Homans, 1961) classifies the income of countries in the world into four income groups, low income, lower-middle income, and uppermiddle income), and high income (high income). The World Bank based on income divides countries in the world based on the economic structure of the high class (upper class), high middle class (upper middle class), low middle class (upper lower class), and low class (lower class).

The economic structure of the Watodiri village community is made based on the contribution of each of their livelihoods to income. As many as seven livelihoods were identified by the people of Watodiri village. Each of them contributed to the income of the community, except for fishermen. The contribution of each mahawean income is structured economically according to the percentage of contribution. The livelihoods of tapping lontar palm are in the top structure with a contribution percentage of $43 \%$. In second position is occupied by the traditional salt industry, or people's salt based on program nomenclature, with a contribution percentage of $28.17 \%$. The livestock business is in the third position with a contribution percentage of $13.99 \%$. The fourth position is occupied by the red brick business with a contribution percentage of $9.47 \%$. Field farming which is the main livelihood of the people of Watodiri village is in the fifth position with a contribution percentage of $5.19 \%$, far below the contribution from the agricultural sector to regional income with residents working as farmers, namely $40 \%-45 \%$, and tenun ikat is in the position the sixth with a contribution percentage of $0.75 \%$. Meanwhile, fishermen are in the lowest structure because they do not contribute to family income.

\footnotetext{
${ }_{1}^{1}$ Muru in the Lamahlot language means prohibition. The prohibited area in this area was then still used for one of the villages in lle Ape District, Muruone, which means a prohibited area or area. Recently, "muru" is understood as a tradition of marine conservation which has been passed down from the village which still preserves Watodiri villagers as supporters of this culture, and is more popular with "badu", which is the tradition of opening and closing conservation areas. In this village there is a conservation area which is traditionally forbidden to enter or be approached within a certain period of time. This area is only allowed twice a year, even for 24 hours, one night and one day (all night and all day), is customarily opened by customary leaders in the afternoon, and is customarily closed the following day in the afternoon.
} 


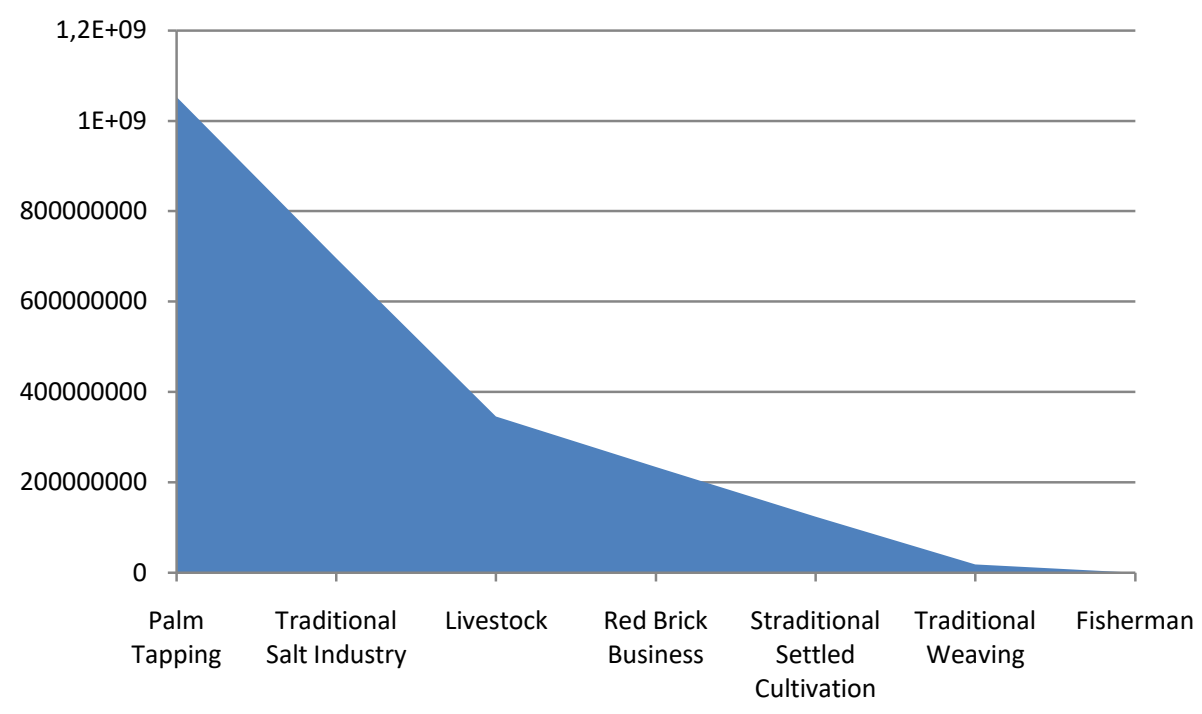

Figure 1 - The Economic Structure of the Watodiri Village Community Based on Contribution to Respondents' Household Income

The economic structure based on its contribution to family income is different from the economic structure based on livelihoods, namely main livelihoods and alternative livelihoods. The analysis shows that as many as three livelihoods that are known to the villagers of Watodiri as their main livelihood, namely field farming in the first position, namely $100 \%$, where all of the residents of Watodiri village live from field farming. In the second position $(92 \%)$, namely palm sap and cattle tapping, it can be said that all the villagers of Watodiri live from tapping palm sap and raising livestock, both large livestock and ruminants. In the following positions with almost the same percentage are the traditional salt industry $(48 \%)$, the red brick business (40\%), and the weaving (36\%).

Table 2 - The Economic Structure of the Watodiri Village Community Based on the Percentage of Basic and Alternative Livelihoods

\begin{tabular}{|l|l|l|l|}
\hline Num & Type of Work & Respondent & $\%$ \\
\hline 1 & Traditional Settled Cultivation & 25 & 100 \\
\hline 2 & Palm Tapping & 23 & 92 \\
\hline 3 & Livestock & 23 & 92 \\
\hline 4 & Traditional Salt Industry & 12 & 48 \\
\hline 5 & Red Brick Business & 10 & 40 \\
\hline 6 & Traditional Weaving & 9 & 36 \\
\hline 7 & Fisherman & 0 & 0 \\
\hline
\end{tabular}

The analysis shows that even though it has a very low contribution to community income, the livelihoods of field farming remain in the top position, or that all the villagers of Watodiri work as field farmers due to tradition. Based on the tradition of corn and cassava are indicators of food safety. In the people's fields, there must be corn and cassava. Failure to harvest corn and cassava is the same as disruption of food security in this village. A lontar palm tapper, although tapping palm leaves in large quantities, affects his energy and time to work on the fields, but in time he has to sacrifice work as palm sap tappers for the sake of cultivating the fields, planting and harvesting corn and cassava in his own fields. This traditional principle is actually a strong basis for community empowerment through an economic empowerment approach. The village government has also seen the weaknesses and activities of this sector, but this is difficult to manifest in the program. 


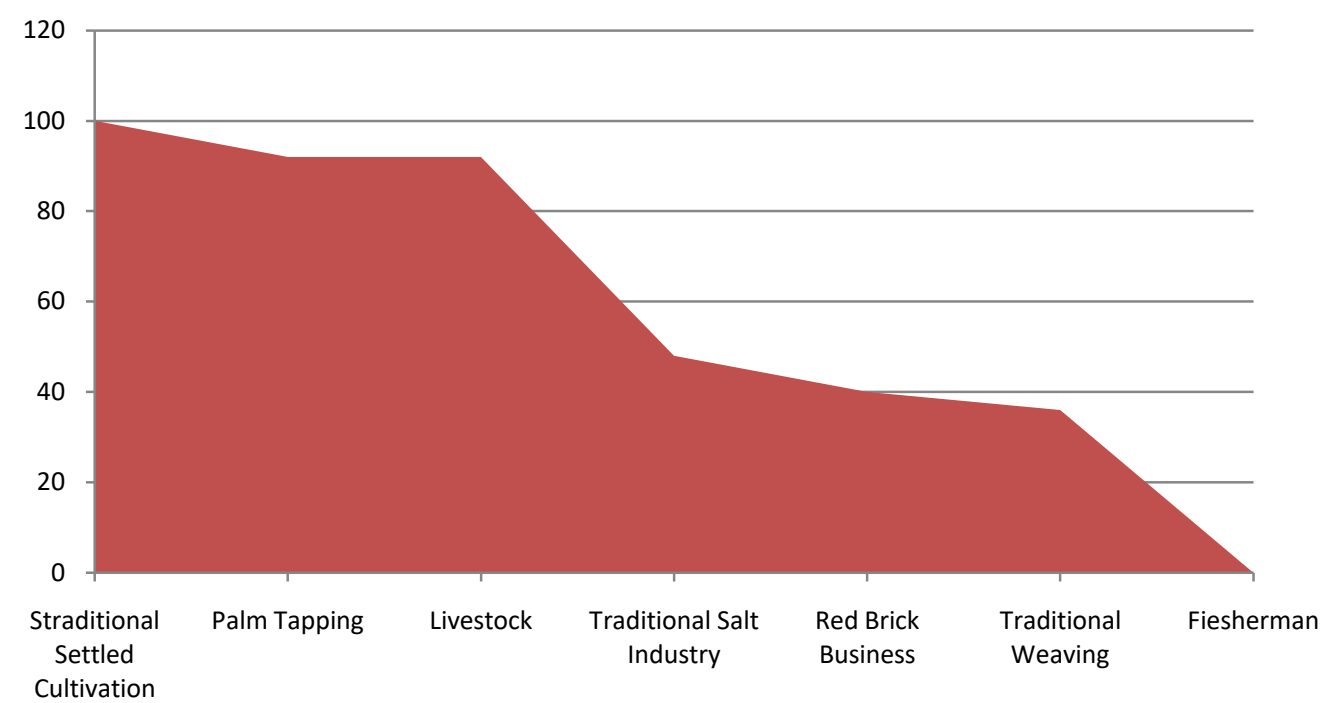

Figure 2 - The Economic Structure of the Watodiri Village Community Based on the Percentage of Basic and Alternative Livelihoods

The Central Government allocates village funds to be managed directly by the community at the village level with the aim of providing answers to chronic problems about poverty in the village. It is hoped that the government and village communities can manage this fund by following models that are in accordance with the conditions that make it difficult for the community concerned to get out of the cycle of rural poverty. The commonly known model is community development. Through the principle of the community development model, funds from the central, provincial and district governments to villages for economic development (empowerment). Intervention through agricultural, livestock, handicraft, fishing programs with extension activities, mentoring, training (Green Jhon J., 2016; Aulia Akbar, et all. 2020). Collaboration with universities, non-governmental organizations and the business world is required. In managing village funds, the village government regulates itself according to the policies that the local government thinks are the best for advancing the community's economy. This tendency of budget management is the weakness of local politics, which is closed and allergic to interventions (Wibisonom et al., 2013). The result is that the allocation of village funds to strengthen the community's economy in the agricultural sector, animal husbandry, and the woven handicraft industry has a very low impact on strengthening the community economy.

A total of seven livelihoods are known to the villagers of Watodiri. Empowerment interventions in relation to strengthening the economy of rural communities have not all received development attention. The livelihoods that are always a concern of development are agriculture and livestock, even tourism for Watodiri village, although this sector has not been included in the economic structure of the Watodiri villagers. Since the inception of the Village Fund, the agricultural sector for agroforestry has always received priority assistance.

The government realizes that the development intervention in the agricultural sector by allocating a budget of $\mathrm{Rp} 52$ million each year to plow agricultural lands belonging to Watodiri farmers has a less significant impact. The production of maize and cassava from plowed land with the land that was cleared was the same, there was no difference. The problem is with the farmers. The cropping pattern follows a known hereditary cropping pattern. Farmers have less attention to the maintenance of maize and cassava plants, so it is common for corn and cassava to languish in competition with wild grass or weeds. Cassava is also planted in very small quantities. One land with an area of 0.5 hectares is planted with at most dozens of cassava cuttings from the supposed 1,200 cassava cuttings. Because of that the production is very low. The problem is the farmers themselves who are difficult to get invited to implement an intensive farming system, which focuses on corn and cassava farming. The village head's mission is to empower farmers to be prosperous, the point is to focus. For 
example, on an area of 0.5 hectare planted with 16,650 cassava steng, and from one cuttings can be harvested 2 kilograms of wet cassava. Production is estimated at 30,000 tonnes. This is still a hope that continues to be pursued.

In 2020, another Rp. 20 million budget is allocated for four farmer groups under the Association of Farmer Groups (Gapoktan), each group receiving Rp. 5 million. This farmer group manages the village irrigation area (village garden) by planting shallots and corn. Farming in Village Gardens utilizes village water, which is a provincial program. Provincial program with a pump machine to irrigate an agricultural expanse equipped with box installations.

When visiting the agricultural location, a brief discussion was held with the Field Agricultural Extension (FAE) and the head and members of the Taansare Farmer Group who were clearing weeds. This farmer group has 14 members. Only 8 people are active. They plant onions and corn in the dry season by utilizing water from a bore well provided by the Provincial Irrigation PU. Plant performance is not good enough. Plants grew languid and were attacked by armyworm pests. Even though the plant's performance is not good enough, in terms of empowerment this is a good start that must be maintained. The chance of crop failure is quite large, and will affect farmers' motivation. If what is experienced is crop failure, farmers will lose their motivation to farm by implementing new innovations. Besides, this group is in trouble with the six members of the group no longer active.

The performance of corn and shallot farming in this place which is 1.5 months old is not good, with the contributing factor is that the irrigation system is not optimal so that it affects the growth performance of plants and pests. PPL or the assistant must make efforts so that the growing performance of shallots and corn can improve in order to obtain optimal production. This is related to the motivation of farmers, who are field farmers who are invited to shift to farming with an irrigation system. What is very important in irrigated agriculture is the existence of farmers on agricultural land. With their daily activities in the location of the business land, farmers can do anything related to plant maintenance (maintaining and caring for planting).

Therefore, farmers who live far from agricultural land are also a problem of farming performance in this place. Farmers are not optimal, plants are not cared for properly. Every time the farmer should be on his farm. "Make the farm as a tourist / recreation place." They must continue to be motivated, encouraged to love farming stronger. For example from Bima people, take the assisted farmers to the place where Bima people farm onions, etc. The Bima people came from Bima to contract the land of the Lembata people to grow onions and vegetables by making the Lembata people work. They live prosperously from farming onions on people's lands by making the local people work for them. With long-term intensive assistance, these farmers are increasingly involved in vegetable farming, because they continue to experience success. The changes that occur within the Taan Sare farmer group will attract other farmers to farm vegetables.

Development interventions in the livestock sector will only begin in 2020 , or five years after the start of the National Village Fund program. In 2020, the village government allocated Rp. 45 million from the Village Fund to bring in 45 piglets for livestock groups to raise. This program is in collaboration with the Livestock Service Office. The piglets were taken from the Livestock Service Office, and then raised by members of the Livestock Group until December 2020, and the Animal Husbandry Service came to buy them for Rp. 3 million. The 45 pigs were distributed to 45 families to be raised. During the August study we monitored the maintenance site; and we found live pigs stressed in the tight and cramped pen. Pigs are still very small even though they have been raised since March 2020 . This reality is very far from an ideal livestock system, such as a healthy pen, made of cement, with a cement floor, large in size so that the pigs can live healthy so that they grow well. The conditions of the pen and pigs are very apprehensive, it can be ascertained that until December it is difficult for pigs in this pen to be sold for Rp. 3 million to Rp. 4 million.

The farmer complained that the aid pigs were too small, and it was difficult to eat the food that was given in the form of cassava and banana stalks. As many as two aid pigs died, which according to the understanding of the farmer as a result of being too small to be 
handed over. The reason is not quite right, when it is related to observations where stress relief pigs were found in very small wooden pens with food that was not eaten and water was not available. Pigs that are under stress have a chance of dying if the breeder does not pay attention to the conditions of the cage, food and water.

The Village Fund is also allocated for the empowerment of women through the Dasa Wisma group, with the target of returning the glory of weaving to women in Watodiri Village. In 2018, Rp 10 million was allocated per hamlet. In 2019, another Rp 8 million per hamlet is allocated. Village funds allocated per hamlet are subsequently managed or used by Dasa Wisma to (1) purchase materials (threads, etc.) for weaving in Dasa Wisma, (2) for lending business for group members at $1 \%$ interest. The funds allocated are very helpful for Dasa Wisma activities; because during the years Dasa Wisma was formed, Dasa Wisma activities have always been stagnant due to funds or capital. With a focus on weaving activities by Dasa Wisma women and borrowing, the Village Fund received by each hamlet of Rp. 18 million has grown. Hamlet I has grown to Rp. 25 million, Hamlet II has grown to Rp. 30 million, Hamlet III has grown to Rp. 26 million and Hamlet IV has grown to Rp. 35 million. This difference is caused by the size of savings by mothers. For women who sell sarongs, for example, money from selling sarongs is given to Dasa Wisma to be used as savings.

The Village Fund for Dasa Wisma, which is then managed for weaving and savings and loans, is very useful, such as with this fund, women in Watodiri village are increasingly active in the activities of the Dasa Wisama group, are easy to get materials for weaving, and are also easy to get funds for the cost of children's education, even through a borrowing mechanism (debt).

The Village Fund for Dasa Wisma activities in Watodiri village is IDR $72,000,000$. This fund was then developed through two activities, namely savings and loans and activities of weaving for women in the village. The proceeds from the sale of the weaving tie are immediately given to the members' savings The financial condition of Dasa Wisama per hamlet as reported by the management is $115,000,000$, with details as explained. Thus it can be said that the growth rate of village funds for Dasa Wisma activities is relatively fast, namely $59.72 \%$ or an average of $29.86 \%$ per year. The village head and village administrators explained that the Village Fund for Dasa Wisma activities is growing rapidly. Village funds allocated for activities of mothers in the Dasa Wisma forum have a positive effect on family income.

In relation to the economic structure of the Watodiri Village community, according to the analysis, economic activities or livelihoods that have been and are currently receiving Village Fund allocations are the agricultural sector (field farming), the livestock sector (pig livestock), and the service / craft sector (weaving). Budget interventions for these three sectors have very low impact. For the agricultural sector, its effect is only limited to reducing the work of the peasants who devote their energy and time to cultivating the land, while the production of field farming that is cultivated with the assistance of the Village Fund does not increase, or the production is still the same as cultivated agricultural land with an outpouring of labor. For the livestock sector, the budget allocation for economic empowerment of breeders through raising pigs is still very far from expectations, with basic problems in the empowerment process. Farmers are not well prepared to accept a market-oriented pig raising program. Farmers raising aid pigs according to the experience of raising local pigs raised for years are sold. The weaving handicraft service sector is of little help, providing an illustration of the successful management of Village Funds allocated for empowerment of this sector. However, this sector is still running based on experiences passed down from generation to generation. Mothers who are active in Dasa Wisma are elderly women, while young women are only four people for all Dasa Wisma. It can be understood that young women with high school education are still less interested in the woven handicraft sector. The basic weakness of the economic empowerment of the Watodiri village community through the agricultural sector, livestock, and woven handicrafts goes outside the non-formal education path, where people are trained and assisted continuously (live long education) in adopting any innovations. For the agricultural sector, the village government brings in tractors for plowing and for the livestock sector; the village government brings in pigs to be 
raised. Funds allocated to these two sectors are managed at the village level, in the same way that rice is cooked by the village government, farmers and ranchers are asked to eat. This is very contrary to the Lamaholot tradition, for eating, the processing and preparation of food are all involved while eating together in that process.

The traditional sector of palm sap tapping, the red brick business, and the people's salt industry which economically contributes greatly to the respondent's income has not received attention in the process of empowering the rural economy through the Village Fund. The traditional salt industry sector received empowerment assistance from the Regency Government with the construction of a building where women make salt, facilities in the form of a large pot for cooking salt, a container for storing salt water from fiber which is very helpful for salt craftsmen. District government assistance has a significant effect on the people's salt business in this place. The building where salt water is processed into salt provides comfort to the salt craftsmen. They stay longer in this place from morning to evening for the activity of processing salt sand into salt water and then into salt. The red brick handicraft sector, which is very potential in Watodiri Village, is taken by investors who come to this place. The land owners leased their land to investors because they did not have sufficient capital to cultivate red bricks. This kind of problem should be answered by the village government through the Village Fund.

The state of the economic structure of the Watodiri Village community is poorly understood, which has an effect on the tendency to fail the Village Fund allocation for community economic empowerment. This fact is the same as explained by Akses Suroto, chairman of the Socio-Economic Strategic Cadre Association, in Jakarta, Sunday, June 7 2015 , that the rural policies implemented by the government ignore the structure of the village economy. The implementation of its policies seems to still follow the neo-classical and neo-liberal views which ignore the problem of the economic structure of rural communities. The policies taken by the government, especially local governments, still consider the cause of village poverty that the community is still fixated on technology inherited from their ancestors, which is of course primitive. It is a neoclassical view that will eventually find failure; and it is the villagers themselves who are blamed; with factors such as mental attitudes, being tied to culture, etc. which on the one hand discredit the village community and on the other hand can be seen as self-defense on the part of the planner. The focus of infrastructure development which is the current priority will eventually fail if it does not pay attention to the crucial problems of the village economic structure. This is actually almost the same or similar to the pro-poor development model for many years which relies on food imports and the increasing gap ratio between the rich and the poor. So far, the central and regional governments have not wanted to overhaul the basic socio-economic structure of village communities so that they are empowered. The economy of rural communities is not yet well structured, which ones are the basis, or the primary sector and which are the secondary and tertiary sectors. So far, villages in Indonesia have not shown much of their superiority to become a trigger for empowering the village economy itself.

The problem of the low response of farmers and breeders to empowerment assistance is also an example of the weakness of the empowerment process. The main thing about empowerment is a thorough understanding of the problems, wants and needs of the community. The people of Watodiri village are traditional farmers and breeders where production and productivity are left to nature, such as soil fertility without fertilization, rainfall, and less intensive maintenance. This fact is in line with Suroto's (2015) explanation that $90 \%$ of the villagers are farmers, fishermen and breeders; but all of them are not real farmers, they are farm laborers, labor farmers, cattle herders, and workers in fishing boats, fishbearers, and fish sellers. All of them are villagers who have no agricultural land, no livestock, and no boats and fishing gear. Everything is controlled by the upper class people in the village, who are landowners, big breeders, and big fishermen who own boats and fishing gear. When assistance came to the village, the villagers whose livelihoods were devoted to labor could only be manipulated by the feudalists in the village for a while, while the villagers could only survive as labor. 
Farmers in Watodiri Village are farmers who control vast agricultural lands and in several places. This is the main capital for empowering the farming community. It is very strange if farmers own vast agricultural lands but always experience economic difficulties. If farmers like this make optimal use of controlled agricultural lands, the farmers in this village are guaranteed to live prosperously. The development approach in the agricultural sector for the villagers of Watodiri should be continuous assistance and education. The program allocating a Village Fund of Rp. 52 million to plow agricultural land owned by farmers apparently did not provide an answer to the problem of poverty being experienced by farmers.

The village government's policy of allocating a budget for empowering farmers and ranchers to plow agricultural lands and buy piglets ignores the philosophy of empowerment and is not in accordance with the goals of the central government. The central government allocates a budget through the empowerment program for the poor with the nomenclature of the Village Fund to provide opportunities for villages to develop the community's economy, through training and marketing of community crafts, developing livestock and fisheries businesses, and developing tourist areas through BUMDes (village-owned enterprises). The key to success for the welfare of the community in building the village is the strong touch of initiation, innovation, creation and collaboration between village officials and the community in realizing what their common goal is. Village development cannot be carried out by village officials alone, but it requires support, initiative and an active role from the community.

This problem is similar with the concern of the central government that the achievements of the Village Fund so far still need improvement. The task of planning, managing and guarding the Village Fund going forward is getting tougher. The government always strives so that the Village Fund can be more pro-poor. In addition, the drafted regulations have resulted in an effective, efficient, and accountable Village Fund management system, so that the government's objectives through the allocation of Village Funds can be realized. For this reason, it is necessary to strengthen institutional capacity and human resources, both village government officials, communities, and village assistance personnel as well as improving transparency, accountability and supervision in the management of Village Funds and village finances (Wibisono et al. (2013: 37). Village government In this case, they should be open to involving the role of universities, nongovernmental organizations, investors in mentoring, training, evaluation and investment.

Farmers in the village should be empowered so that they can change from being a permanent field farmer by simply surrendering their entire amount to the generosity of nature to being a forward-oriented farmer by applying a modern farming system starting from planning, implementation and evaluation. Hereditary subsistence farming with village funds can be increased by intensive palawija farming and horticultural farming. Agriculture in this village can be all year round. During the rainy season the land is planted with maize and cassava, the recommendation pattern is mainly related to spacing in relation to the optimization of agricultural land. Farmers who have 1 hectare of land can plan 0.5 hectares only to plant corn and 0.5 hectares only to plant cassava. Plant maintenance also needs attention. So that for several days it does not rain, so that the plants do not languish, it should be watered. The same rights are also applied to other sectors, such as livestock, palm oil tapping, and the red brick business. BUMDes was not yet formed at the time of the research because of the problem of the type of leadership which is inward looking, which only relies on its own very limited capabilities.

Thoughts like these are closely related to the successful management and accountability of the use of Village Funds to the beneficiary community. Various parties who doubt the success of Village Fund management by village communities focus more on human resources $(\mathrm{HR})$ at the village level. It can be said that doubts about the success of the Village Fund management have become a habit for those who criticize community empowerment programs. When this country gave confidence to the poor to empower itself with the approach of providing cash assistance known as the Inpres Village Disadvantaged Program of 1994, many people previously highlighted weaknesses and claimed the failure of 
the IDT program, with examples of cases in regions; which is also being experienced by Watodiri Village in managing the Village Fund for community empowerment and welfare.

The Community Empowerment Program is clearly stated in our State Policy Guidelines (GBHN), but it is extremely difficult to execute programs that directly touch the interests of the community, especially the interests of the rural poor. Our State Policy Guidelines (GBHN) emphasize that the goal of our national development is human development, namely the development of the whole Indonesian people and the development of the entire Indonesian society. The definition of human and community development as whole and comprehensively is further elaborated in the formulation (1) there is harmony, harmony and balance between physical and mental development, (2) equitable development throughout the country, and (3) development for all groups, all groups, community members and all the people.

These human-oriented elements of national development can be distinguished from production-oriented development. David Korten (in Mubyarto and Kartodirdjo, 1988: 70) explains that the critical difference between production-oriented development and humanoriented development is that humans are first placed as a subordinate of the production system. Meanwhile, human-oriented development is what is needed in the production system to fulfill human needs. Human in this case is not a means or machine of production, but the subject who runs the production machine. Production-oriented development prioritizes the development of production systems and efforts to increase production efficiency. Humans are seen more as part of the production system, by placing capital as the main resource of the economic system and production system.

A human-centered development approach (people centered development), the main resources of the production system are the thoughts, initiatives and creativity of the humans themselves, so that the basic strategy is the optimal use of resources. Human-oriented national development also emphasizes the characteristics of participatory development, where planning, implementation, and evaluation are carried out jointly with the community. In its implementation, participatory development ignores the fulfillment of human needs (human needs) and focuses more on an independent organizational system directed at the creation of socio-economic conditions of life, in which it is easier for people to meet their own needs in ways that they develop themselves wherever possible.

When the central government considers it important to have a business entity at the village level as a Village-Owned Enterprise (BUMDes), it is actually easy for village governments to establish BUMDes in villages. Watodiri Village has very prospective businesses that can become BUMDes business units such as tapping palm sap, which contributes a lot to income. The business of lontar palm juice attracted billions of rupiah in cash to Watodiri Village which had a strong influence on the dynamics of development in this village. Another prospective business unit is the red brick business, which is actually taken by investors who come from outside. Meanwhile, the village government had difficulty establishing BUMDes. The village government should have the courage to allocate a budget, for example Rp. 300 million for the red brick business unit. BUMDes manages it with the Red Brick business or business mechanism. BUMDes provides funds to a red brick business group, with up to five families as members. The payback is the current year as soon as the red brick is sold. One group is allocated Rp. 10 million, so BUMDes manages 30 red brick groups in this village. The refund agreement six months later with an interest of $6 \%$, the BUMDes will charge an interest of Rp. 600,000 per group, or six months later, the total interest taken by BUMDes from the red brick business with BUMDes' loan capital is Rp. 18 million, which is of course very large for BUMBes.

Palm wine tapping and the red brick business are very potential in this village, and unexpectedly have long been the economic base of the Watodiri village community. Up to now, both businesses in the traditional sector have escaped development interventions. Village funds are also missing from these two potential sectors, even though the people themselves know that the income from these two sectors is very large. Due to the absence of development interventions, these two sectors operate in a hereditary pattern. A young entrepreneur said that when he was troubled about work problems, he came to the village and tried to work on making red bricks. It turns out that this business provides a large income 
if it is carried out with clear management and targets. Unexpectedly, he later turned into a young entrepreneur in the red brick business sector. The results are:

"I have unconsciously done work in a manufacturing business, where in management science we have to be ready from upstream to downstream, where the initial processes of manufacture, printing, drying, burning and distribution must be understood. Not only that, in terms of paying wages, I also have to learn everything, of course I am assisted by 2 supervisors who have subordinates who are their responsibility. I also feel happy with this entrepreneurial job which has become my unforgettable experience with my condition that I have to be able to handle a business that other people think is very complicated, especially when we have to have our own transport car, which we must pay attention to the driver and the vehicle. Sometimes it is a difficult job, if we are in a tight situation, finally I can master it well".

Government intervention in rural development is an important factor in the process of change in the village. Government intervention through the Village Fund program for the economic system at the village level is sure to change the economic system of rural communities. The red brick business in Watodiri village has great potential, absorbs labor in the village, and has a high contribution to income. However, the residents of Watodiri village are reluctant to make the red brick business their main job. The potential of the red brick business in this village has become a target of profitable investment for several lower-middleincome investors who come to this village to invest by leasing land to cultivate red bricks by employing workers imported from outside the region. If these potentials become BUMDes business units, by applying modern management, in just 2-3 years Watodiri village will become a village with a developing economy based on red brick business, tapping palm sap, livestock, agriculture, salt industry, and weaving crafts.

This study shows that the development intervention in Watodiri village, although getting more intensive with the increasing amount of funds, is difficult to bring this community out of its traditional social and economic conditions. The problem is as explained by development anthropologists that (1) farmers still love their traditional lifestyle which is thick with a brotherly atmosphere, (2) farmers still love a simple lifestyle with sufficient support from subsistence economic activities; or farmers still love a mediocre lifestyle, (3) the technology introduced by farmers is less superior than the technology they have mastered, (4) the technology introduced is not what they expect, (5) farmers are reluctant to accept the lifestyle capitalist-consumptive, such as by means of maximizing agricultural production who inevitably serve under loans (see also David Korten, in Mubyarto and Kartodirdjo, 1988: 70).

Points of thought like this are consistent with the findings of research on the impact of village fund management on changes in the economic structure of the Watodiri village community in Ile Ape District, Lembata Regency, East Nusa Tenggara. The Village Fund for almost five years has had a low impact on the improvement of the economic structure of the Watodiri village community. The allocation of village funds for economic empowerment in the fields of agriculture, livestock, and the weaving industry has not been able to advance these three sectors with the main constraints on local politics, or less impartial village government policies. The allocation of village funds for the three economic activities is not based on sound and measured studies and planning. The problem of low education, the condition of critical agricultural land, difficulty in reaching the market, and difficulty in obtaining capital as seen by agricultural socio-economic experts is not reasonable if it is used as an inhibiting factor for the success of economic empowerment of the Watodiri village community with village funds and a number of other funds that allocated each year.

\section{CONCLUSION}

The economy of the Watodiri Village community is structured based on the contribution to the income and main livelihoods of the villagers.

Based on the contribution to the economic family income of the structured Watodiri village community, the tapping of palm sap occupies the top structure with a contribution of 
$43 \%$, successively the traditional salt industry is $28.17 \%$, livestock $13.99 \%$, red brick business $9.47 \%$, field farming $5.19 \%$, weaving $0.74 \%$, while fishermen $0 \%$.

The seven economic activities in Watodiri village are traditional activities, and based on the community's understanding of the main work of field farming is in the highest structure because all $(100 \%)$ of the inhabitants of Watodiri Village are subsistence semi-permanent farmers, followed by $92 \%$ of the population are breeders and tappers. nira lontar, $48 \%$ of the population are salt craftsmen, $40 \%$ of the population are craftsmen of red brick and weaving $(36 \%)$, while even though this village is located on the coast, there are no fishermen.

The community empowerment program, which is increasingly intensive in coming to Watodiri village, has not yet affected changes in the economic structure of the villagers. The seven activities or livelihoods studied so far are still traditional economic activities that are highly dependent on natural resource potential, such as field farming which is prone to crop failure due to insufficient and erratic rain.

In managing village funds, the village government regulates itself according to the policies that the local government thinks are the best for advancing the community's economy. The result is that the allocation of village funds to strengthen the community's economy in the agricultural sector, animal husbandry, and the woven handicraft industry has a very low impact on strengthening the community economy. The economy of the Watodiri village community remains in a subsistence condition.

\section{SUGGESTIONS}

The economic structure of rural communities should get attention in conducting empowerment interventions.

Tapping lontar sap, red brick business, livestock (cows, pigs, goats), the people's salt industry, and woven fabrics are potential economic activities that could be better managed through BUMDes.

Empowerment of the poor with a community development and economic empowerment model must go through a well-planned and measured process or stages involving stakeholders, such as universities, non-governmental organizations, and the business world.

Non-formal education such as course and training should be an important consideration in the empowerment process

Traditional economic activities in the agricultural sector, livestock, palm wine tapping business, traditional salt business, red brick business, and weaving business by women should be optimized as a potential economic base for the people of Watodiri Village.

\section{REFERENCES}

1. Adnan, N., Nordin, S. M., Bahruddin, M. A., \& Tareq, A. H. (2019). A state-of-the-art review on facilitating sustainable agriculture through green fertilizer technology adoption: Assessing farmers' behavior. Trends in Food Science \& Technology, 86, 439-452.

2. Achmadi, A. N. C. 2008. Metodologi Penelitian, Jakarta: Bumi Aksara.

3. Ali, D. A., Bowen, D., \& Deininger, K. (2020). Personality traits, technology adoption, and technical efficiency: evidence from smallholder rice farms in Ghana. The Journal of Development Studies, 56(7), 1330-1348.

4. Arsyad Lincolin. 2004 Ekonomi Pembangunan.Yogyakarta: Sekolah Tinggi Ekonomi.

5. Aubert, B. A., Schroeder, A., \& Grimaudo, J. (2012). IT as enabler of sustainable farming: An empirical analysis of farmers' adoption decision of precision agriculture technology. Decision support systems, 54(1), 510-520.

6. Barlett, P. F. (Ed.). (2016). Agricultural decision making: Anthropological contributions to rural development. Academic Press.

7. Bridle, L., Magruder, J., McIntosh, C., \& Suri, T. (2020). Experimental Insights on the Constraints to Agricultural Technology Adoption.

8. Chavas, J. P., \& Nauges, C. (2020). Uncertainty, Learning, and Technology Adoption in Agriculture. Applied Economic Perspectives and Policy, 42(1), 42-53. 
9. Cancian, F. (1979). The innovator's situation: Upper-middle-class conservatism in agricultural communities. Stanford University Press.

10. Fay, Y., Klau, F. and Nainiti, S.P.N. (2018). Analisis Curahan Tenaga Kerja Wanita Pada Usahatani Jagung di Lahan Kering Zona Illay di Kabupaten Kupang. Jurnal Excelentia ISSN: 2301-6019 Vol. VII No. 1 Juni 2018.

11. Hart, Gillian, et al (editors). (1989) Agrarian Transformation Local Processes and the State in Southeast Asia. Berkley, Los, London: University of California Press.

12. Hernanto, F.(1998). IImu Usahatani. Penebar Swadaya Jakarta.

13. Hermans, F., Stuiver, M., Beers, P. J., \& Kok, K. (2013). The distribution of roles and functions for upscaling and outscaling innovations in agricultural innovation systems. Agricultural Systems, 115, 117-128.

14. Homans, George. (1961). "Status, Conformity, and Innovation" https://www.cnnindonesia.com

15. Koentjaraningrat. (1985) "Masyarakat Pedesaan di Indonesia", dalam Koentjaraningrat (editor), Masalah-Masalah Pembangunan Bunga Rampai Antropologi Terapan.

16. Lamprinopoulou, C., Renwick, A., Klerkx, L., Hermans, F., \& Roep, D. (2014). Application of an integrated systemic framework for analysing agricultural innovation systems and informing innovation policies: Comparing the Dutch and Scottish agrifood sectors. Agricultural Systems, 129, 40-54.

17. Lauer, Robert H. (1989). Perspektif Tentang Perubahan Sosial. Alimandan (Penerjemah). Jakarta: Bina Aksara.

18. Mubyarto. (1993). Pengantar Ekonomi Pertanian. LP3ES Jakarta.

19. Mulyadi, 2007. Membangun Kesadaran and Keberdayaan Petani. Diakses Dari Internet tanggal 13 April 2016.

20. Notoatmodjo. (2010). Metodologi Penelitian. Jakarta: Rhineka Cipta.

21. Roidah, I. S. (2015). Analisis pendapatan usahatani padi musim hujan and musim kemarau (studi kasus di Desa Sepatan Kecamatan Gondang Kabupaten Tulungagung). Jurnal Agribis, 11(13), 45-55.

22. Singarimbun, M., \& Effendi, S. (1995). Metode Penelitian Survei, PT. Pustaka LP3ES.

23. Sinu, Ignatius. (1992). Adopsi Inovasi Teknoligi Pertanian Sawah Oleh Masyarakat Petani Sawah di Daerah Persawahan Konga, Kecamatan Wulanggitang, Kabupaten Flores Timur Nusa Tenggara Timur. Penelitian Dengan Biaya Kementerian Lingkungan Hidup.

24. Sinu, Ignatius. (1994). Inovasi Teknologi Pertanian and Kehidupan Ekonomi and Sosial Budaya Masyarakat Petani Waikomo-Lewoleba Lembata Flores Timur Nusa Tenggara Timur. Thesis S-2 Program Pascasarjana Antropologi Universitas Indonesia.

25. Sinu, Ignatius (editor) (2007). Belajar Melihat Ke Depan Dari Masa Lalu. Pemda Alor and Para Penulis: Kupang.

26. Sinu, Ignatius. (2015). Revolusi Pertanian di Sabu Raijua, Serpihan-Serpihan Pemikiran and Pengalaman dari Sabu Raijua. Jakarta: Kandil Semesta.

27. Soekartawi (2001). Analisis Usahatani. UI Press. Jakarta.

28. Suek, J., dkk. (1996). Ragam Pendapatan and Kontribusi Kacang-Kacangan Terhadap Pendapatan Rumah Tangga di Hulu and Hilir DAS Oesao. Laporan Penelitian Faperta Undana Kupang.

29. Sugiarto, Caca (2018). "Teknologi Pertanian Terbaru di Indonesia and Praktiknya", Artikel Online, Juni 2018.

30. Suparyono and Setyono, A. 2003. Padi. Jakarta: Penebar Swadaya.

31. Tang, F.M., Wiendiyati, and F. Klau. (2018). Analisis Pendapatan and Faktor-Faktor Yang Mempengaruhi Produksi Kacang Hijau di Desa Nunkurus Kec. Kupang Timur Kab. Kupang. Jurnal Excelentia ISSN: 2301-6019 Vol. VII No. 2 Desember 2018.

32. Taylor, Steven and Robert Bogdan (1982). Introduction to Qualitative Research Methods. New York: A Wiley-Interscience Publication.

33. Warisno and Dahana Kres. (2010). Meraih Keuntungan Dari Kedelai. Jakarta: Kansius.

34. Wibisono, H. K., Trianita, L. N., \& Widagdo, S. Dimension of Pancasila Ethics in Bureaucracy: Discourse of Governance. Kearifan Lokal, 15. 